\title{
Effect of lead nitrate on the ovaries of the striped snakehead Channa striatus (Bloch, 1793)
}

\author{
SHIVANI SHARMA ${ }^{1}$, VIPIN VYAS 2 , SADHNA TAMOT ${ }^{3}$ AND GHANSHYAM N. JHA ${ }^{4}$ \\ ${ }^{1}$ Department of Zoology and Applied Aquaculture, Barkatullah University, Bhopal - 462 026, Madhya Pradesh, India \\ ${ }^{2}$ Department of Biosciences, Barkatullah University, Bhopal - 462 026, Madhya Pradesh, India \\ ${ }^{3}$ Department of Zoology, Sadhu Vaswani College, Bairagarh, Bhopal - 462 026, Madhya Pradesh, India \\ ${ }^{4}$ Krishi Vigyan Kendra, Sher-e-Kashmir University of Agricultural Sciences and Technology of Jammu, Bhaderwah \\ Doda - 182 221, Jammu and Kashmir, India \\ e-mail:ss.shivani001@gmail.com
}

\begin{abstract}
The effect of sublethal concentrations of lead nitrate $\left(0,8,18\right.$ and $\left.28 \mathrm{mg} \mathrm{l}^{-1}\right)$ on the ovaries of the freshwater murrel Channa striatus (Bloch, 1793) (average length : 20-25 cm; average weight : 50-60 g), randomly distributed (ten fishes per group) into four groups (control, Exp-1, Exp-2 and Exp-3, respectively), were studied in triplicate. Each group of fishes were exposed to lead nitrate for 90 days with the aim to assess the histoarchitectural alterations in the ovaries, at different time intervals. Loosening of connective tissue, deshaped primary oocytes, damaged epithelial layer of oocytes, decreased number of yolk granules in secondary oocytes, upliftment of epithelial layer of secondary oocytes, comparatively decreased number of primary oocytes, necrosis, damaged and irregular shaped oocytes and inflammation were common features in all the three experimental groups exposed to sublethal concentrations of lead nitrate. Severity of the above features increased with increased lead nitrate concentration and duration of exposure.
\end{abstract}

Keywords: Channa striatus, Histoarchitecture, Lead nitrate, Murrel, Ovaries

Heavy metal contamination is an ongoing problem leading to damage of aquatic life, especially fishes and therefore, it has become a major researchable environmental issue of concern (Gill et al., 1990; Hunaiti and Soud, 2000). There are number of routes by which heavy metals enter aquatic habitat causing cytotoxic, mutagenic and carcinogenic effects in aquatic organisms (More et al., 2003; Thirumavalan, 2014). Lead is abundantly found in the earth's crust and has widespread industrial applications (Palaniappan et al., 2008). Once introduced into the aquatic ecosystem lead causes severe intimidation to aquatic life and it is notorious to cause severe histological and metabolic alterations in fishes. Histopathological and histoarchitectural changes are being widely used as reliable indicators to study the health of fishes exposed to contaminants (Wester and Canton, 1991; Hinton et al., 1992; Schwaiger et al., 1997; Thophon et al., 2003; Dar and Jha, 2013). Histoarchitectural changes emerge as a medium-term response to sub-lethal stressors and histology also provides a quick technique to identify effects of pollutants in various tissues of organisms (Johnson et al., 1973; Dar et al., 2014). Therefore, the present study was designed with the aim to investigate histoarchitectural changes induced by chronic exposure to lead nitrate in the ovary of the freshwater murrel Channa striatus (Bloch, 1793).
Live specimens of $C$. striatus (length 20-25 cm and weight 50-60 g) were collected from different fish markets in Bhopal, Madhya Pradesh and acclimatised to laboratory conditions for a period of 15 days prior to the experiment. Fishes were divided into four groups of 10 fishes each (Control, Exp-1, Exp-2 and Exp-3) and were exposed to sublethal concentrations $(0,8,18$ and $28 \mathrm{mg} \mathrm{l}^{-1}$ respectively) of lead nitrate (Ranbaxy India Ltd.), in triplicate for a total period of 90 days. Exposure concentration was decided on the basis of $96 \mathrm{~h} \mathrm{LC}$ value of lead nitrate. The median lethal concentration $\left(\mathrm{LC}_{50}\right)$ values at $95 \%$ confidence limits for different exposure period were calculated using the software "Trimmed Spearman Karber method", version-1.5 (Hamilton et al., 1977). The $\mathrm{LC}_{50}$ value was observed to be $284.3 \mathrm{mg} \mathrm{l}^{-1}$. To maintain desired lead nitrate concentration throughout the experimental duration of 90 days, water in each aquarium tank was changed on every alternate day. At regular intervals of 30 days (at the end of $30^{\text {th }}$, $60^{\text {th }}$ and $90^{\text {th }}$ days of experimentation), three fishes from each group were sampled and the ovaries were dissected out and fixed in aqueous Bouin's fixative for 48 to $72 \mathrm{~h}$ (Luna, 1992). After fixation, the tissues were processed (Luna, 1992), embedded in paraffin wax and 5-6 $\mu \mathrm{m}$ thick sections were cut with the help of rotatory microtome and 
stained with Ehrlich's haematoxylin and eosin (H\&E) for histopathological examinations. The sections were examined under a trinocular compound microscope (Olympus) and photomicrographs were taken.

Histological sections of the ovaries of the experimental fishes are shown in Fig. 1 (a-j). Histological section of the ovaries of control fish showed normal architecture, characterised by ovigerous lamellae having both primary and secondary oocytes (Fig.1a). Increased histoarchitectural alterations were observed in the ovaries of experimental fishes in proportion with increase in concentration as well as period of exposure to sublethal levels of lead nitrate.

Experimental fishes in the group, Exp-1 exhibited loosening of connective tissue, irregular shaped and deshaped primary oocytes on the $30^{\text {th }}$ day of lead nitrate exposure (Fig. 1b), clustering of oocytes and damaged epithelial layer of oocytes on the $60^{\text {th }}$ day (Fig. 1c) and loosening of connective tissue, damaged secondary oocytes and mild inflammation on the $90^{\text {th }}$ day of exposure (Fig. 1d).

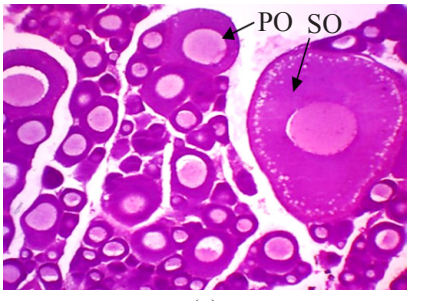

(a)

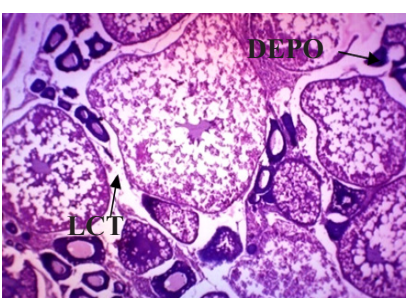

(e)

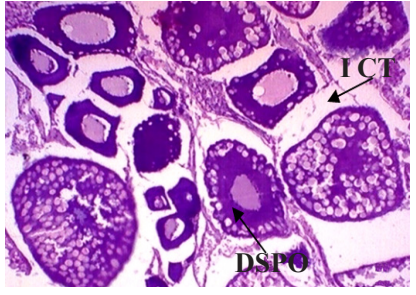

(b)

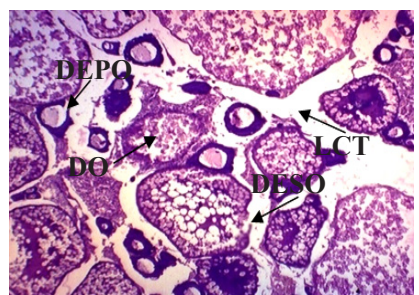

(f)

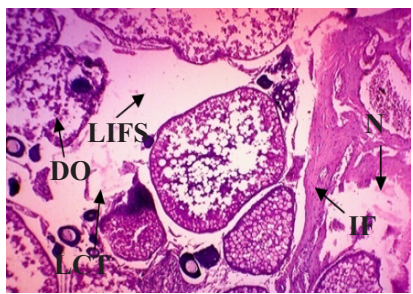

(h)

In Exp-2 fishes, clustering of oocytes, mild loosening of connective tissue and damaged epithelial layer of primary oocytes on $30^{\text {th }}$ day (Fig. 1e), loosening of connective tissue, irregular shaped oocytes, indistinguishable secondary oocytes, damaged epithelial layer of primary and secondary oocytes and damaged oocytes on $60^{\text {th }}$ day (Fig. 1f) and loosening of connective tissue, comparatively decreased number of primary oocytes, necrosis, damaged epithelial layer of oocytes, damaged and irregular shaped oocytes as well as inflammation on the $90^{\text {th }}$ day of lead nitrate exposure (Fig. 1g) were observed.

The common histoarchitectural changes observed in case of Exp-3 fishes on the $30^{\text {th }}$ day of lead nitrate exposure were loosening of connective tissue, clustering of oocytes, irregular shaped oocytes and damaged epithelial layer of primary oocytes (Fig. 1h). The alterations were more severe as extensive loosening of connective tissue, thickening and damaged ovarian wall, comparatively less number of oocytes along with severe inflammation, necrosis, damaged oocytes, decrease in the number of yolk granules and large interfollicular space on the $60^{\text {th }}$ and $90^{\text {th }}$ days of exposure (Fig. 1, i and $\mathrm{j}$ respectively).

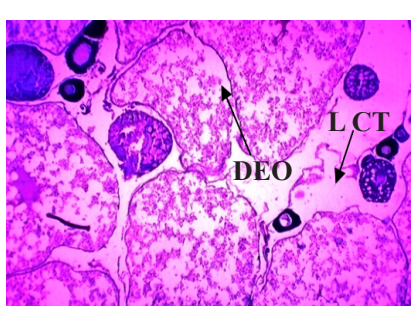

(c)

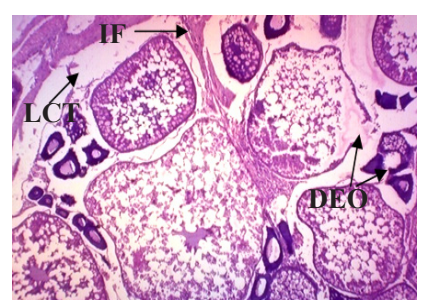

(g)

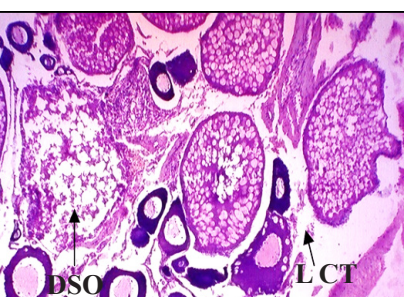

(d)

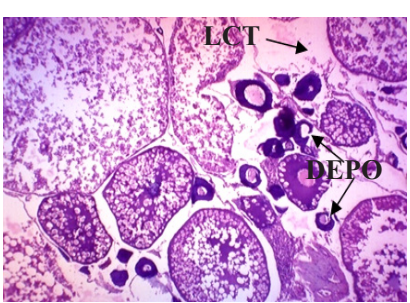

(g)

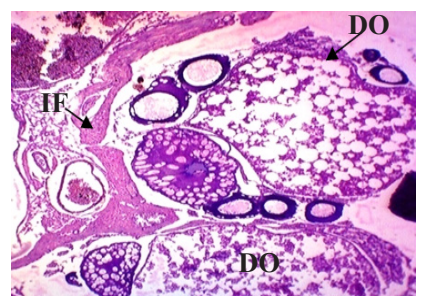

(g)

Fig. 1. Histological sections of ovary of C. striatus (a) Control group, (b) Exp-1 group after 30 days, (c) Exp-1 group after 60 days, (d) Exp-1 group after 90 days, (e) Exp-2 group after 30 days, (f) Exp-2 group after 60 days, (g) Exp-2 group after 90 days, (h) Exp-3 group after 30 days, (i) Exp-3 group after 60 days, (j) Exp-3 group after 90 days.

LCT - loosening of connective tissue, DSPO - deshaped primary oocytes, DEO - clustering of oocytes and damaged epithelial layer of oocytes, IF - inflammation, DEPO - damaged epithelial layer of primary oocytes, DEO - damaged epithelial layer of oocytes, DO - damaged oocytes, N - Necrosis, LIFS - large interfollicular spaces (H\&E; X 100) 
Several authors have reported toxicological changes in the ovaries of fish exposed to heavy metals. Adeymo (2008) observed similar results in C. gariepinus exposed to different concentrations of lead nitrate for a period of eight weeks. Disruption of follicular lining around the oocytes, damaged stroma, less number of pre-vitellogenic and vitellogenic oocytes were observed by Jaat et al. (2013) due to chronic exposure to mercuric chloride for 60 days in the ovary of C. gariepinus. Masarat et al. (2014) reported damaged follicular lining, deshaped oocytes, clamping of primary oocytes, damaged oocytes and reduction in the number of oocytes along with necrosis in the ovaries of C. gariepinus on exposure to $0.008 \mathrm{mg} \mathrm{l}^{-1}$ of mercuric chloride for 60 days. It is clear from the present study that the ovaries of $C$. striatus are affected by even a sublethal dose of $8 \mathrm{mg} \mathrm{l}^{-1}$ of lead nitrate, while most severe damage occurred on the $60^{\text {th }}$ and $90^{\text {th }}$ day of exposure to 28 $\mathrm{mg} \mathrm{l}^{-1}$ lead nitrate.

\section{Acknowledgements}

The authors are thankful to the Head, Department of Zoology and Applied Aquaculture, Barkatullah University, Bhopal (M.P) India, for providing necessary laboratory facilities to carry out the present work successfully.

\section{References}

Adeyemo, O. K. 2008. Histological alterations observed in the gills and ovaries of Clarias gariepinus exposed to environmentally relevant lead concentrations. J. Environ. Health, 70(9): 48-51.

Dar, B. A. and Jha, G. N. 2013. Protective effects of dietary Spirulina against cadmium chloride exposed histoarchitectural changes in the kidney of a freshwater catfish, Clarias batrachus. J. Inland Fish. Soc. India., 45(2): 1-7.

Dar, B. A., Khaliq, R., Jha, G. N., Kour, P. and Qureshi, T. A. 2014. Protective effects of dietary Spirulina against cadmium chloride exposed histoarchitectural changes in the liver of a freshwater catfish, Clarias batrachus. Indian J. Fish., 61(3): 83-87.

Gill, T. S., Tewari, H. and Pande, J. 1990. Use of the fish enzyme-system in monitoring water quality: effects of mercury on tissue enzymes. Comp. Biochem. Physiol., 97(2): 287-292.

Hamilton, M. A., Russo, R. C. and Thurston, R. V. 1977. Trimmed Spearman-Karber method for estimating median lethal concentration in toxicity bioassays. Environ. Sci. Technol., 11 (7): 714-719.

Hinton, D. E., Baumann, P. C., Gardner, G. R., Hawkins, W. E., Hendricks, J. D., Murchelano, R. A. and Okihiro, M. S. 1992. Histopathological biomarkers. In: Huggett, R. J., Kimerle, R. A., Mehrle, P. M., Jr. Bergman, H. L., (Eds.),
Biomarkers: biochemical, physiological and histological markers of anthropogenic stress, Lewis Publishers, Boca Raton, FL, p. 155-209.

Hunaiti, A. A. and Soud, M. 2000. Effect of lead concentration on the level of glutathione, glutathione S-transferase, reductase and peroxidase in human blood. Sci. Tot. Environ., 248: 45-50.

Jaat, A., Saroch, J. D., Shrivastav, R., Qureshi, T. A., Manohar, S., Shrivastava, P. and Borana, K. 2013. Ameliorative effect of Spirulina on the histology of ovary of mercuric chloride effected fish, Clarias gariepinus. Int. J. Green Herb. Chem., 2(1): 130-138.

Johnson, L. L., Stehr, C. M., Olson, O. P., Myers, M. S., Pierce, S. M. and Wigren, C. A. 1973. Chemical contaminants and hepatic lesions in winter flounder, Pleuronectus americanus from the north-east coast of the United States. Environ. Sci. Technol., 27: 2759-2771.

Luna, L. G. 1992. Histopathological methods and colour atlas of special stains and tissue artifacts. Gaithersburg, MD: American Histolabs, Inc.

Masarat, J., Borana, K. and Sujjad, N. 2014. Effect of mercuric chloride on histology of ovaries of African catfish, Clarias gariepinus. In. J. Res. App. Nat. Soc. Sci., 2(5): 107-110.

More, T. G., Rajput, R. A. and Bendela, N. N. 2003. Impact of heavy metals on DNA content in the whole body of freshwater bivalve. Lamelleiden marginalis. Environ. Sci. Pollut. Res., 22: 605-616.

Palaniappan, PL. RM., Sabhanayakam, S., Krishnakumar, N. and Vadivelu, M. 2008. Morphological changes due to Lead exposure and the influence of DMSA on the gill tissues of the freshwater fish, Catla catla. Food Chem. Toxicol., 46: 2440-2444.

Schwaiger, J., Wanke, R., Adam, S., Pawert, M., Honnen, W. and Triebskorn, R. 1997. The use of histopathological indicators to evaluate contaminant-related stress in fish. J. Aquat. Ecosys. Stress Rec., 6: 75-86.

Thirumavalan, R. 2014. Effect of mercuric chloride on lipid peroxidation and glutathione in the freshwater fish, Catla catla. Int. J. Modn. Res. Revs., 2(3): 129-131.

Thophon, S., Kruatrachue, M., Upathan, E. S., Pokethitiyook, P., Sahaphong, S. and Jarikhuan, S. 2003. Histopathological alterations of white seabass, Lates calcarifer in acute and subchronic cadmium exposure. Environ. Pollut., 121(3): 307-320.

Wester, P. W. and Canton, J. H. 1991. The usefulness of histopathology in aquatic toxicity studies. Comp. Biochem. Physiol., 100(1-2): 115-117. 